\title{
THERE IS No SUCH THING AS A SHAM TRUST
}

BoHao (Steven) Li*

The Court of Appeal decision in Official Assignee v Wilson is the leading New Zealand case on "sham trusts". Obiter, O'Regan and Robertson JJ held that for a sham trust to exist, the settlor and trustee must have a common intention to not create a trust. Post-Wilson, debate continues over the precise elements that render a trust a sham. The Law Commission suggested that the sham doctrine, as a means of analysing the validity of an express trust, may not be the best approach. A better starting point would be a return to the certainty of intention requirement. In arguing that the Law Commission's recommendation is correct, this article will discuss three legal issues: whether an express trust is a unilateral or bilateral transaction; whether the excluded evidence has always been part of the objective intention requirement; and whether the legislative and policy factors have made foreign trust law distinct from New Zealand trust law. Finally, this article will expand on the test proposed by the Law Commission.

\section{INTRODUCTION}

The Law Commission ${ }^{1}$ recently reviewed the law on "sham trusts". ${ }^{2}$ A finding of a sham trust denies the validity of a trust thereby enabling third party access to trust-held assets. ${ }^{3}$ In New Zealand, most sham trust claims target inter vivos family trusts. The increasing popularity of such claims is not surprising given that the family trust has become a popular mechanism for estate planning and asset protection purposes. ${ }^{4}$

* The article was submitted as part of the LLB(Hons) programme at Victoria University of Wellington. I would like to thank Professor Tony Angelo for his excellent supervision. I would also like to thank Professor Graeme Austin for nominating me to the LLB(Hons) programme in 2012. Finally, I would like to thank mum and dad for their continuous support and love.

1 Law Commission Some Issues with the Use of Trusts in New Zealand (NZLC IP20, 2010).

2 The phrase "sham trust" came into use internationally after the Royal Court of Jersey decision in Rahman $v$ Chase Bank (CI) Trust Co Ltd [1991] JLR 103 [Rahman].

3 Law Commission, above n 1 , at 13 and 38.

4 Jessica Palmer "Sham Trusts" in A Butler (ed) Equity and Trusts in New Zealand (2nd ed, Thomson Reuters, Wellington, 2009) at 394; Nicola Peart "Can Your Trusts be Trusted?" (2009) 12 Otago L Rev 59; 
The leading New Zealand case on "sham trusts" is the Court of Appeal decision in Official Assignee $v$ Wilson (Wilson). ${ }^{5}$ The Court's remarks on "sham trusts" were obiter because the Assignee's case was dismissed on the technical ground that the Assignee had no standing to make a sham claim. ${ }^{6}$ Nevertheless, the Court went on to consider whether the intention required for a sham finding was that of the settlor only or also of the trustees. Prior to Wilson, the intention requirement was the subject of academic debate between Jessica Palmer ${ }^{7}$ and Matthew Conaglen. ${ }^{8}$

For Palmer, "sham trusts" are concerned with the intention necessary to form a valid trust, namely certainty of intention, which relates only to the settlor. Palmer's view has merit. "Sham trust" is merely a label indicating that there was no trust. A sham trust declaration and a no certainty of intention finding achieve the same result: the trust is declared void ab initio. ${ }^{9}$ Why should a trust not be collapsed in the same manner in which it was created?

In their joint judgment, O'Regan and Robertson JJ (the Judges) rejected Palmer's argument. They favoured Conaglen's argument. To establish a sham trust the settlor and trustee must have a common intention to not create a trust. ${ }^{10}$ The Judges emphasised that while the creation of a valid express trust requires the intention only of the settlor, that principle does not apply to any transaction that purports to be a trust for the following reasons: ${ }^{11}$

(1) Not all trust transactions are unilateral. Where a trust transaction is bilateral, the common intention requirement is appropriate.

(2) Where a sham is alleged, the court can take into account otherwise excluded evidence under the objective certainty of intention inquiry.

(3) Foreign cases favour the common intention requirement.

(4) Promotion of commercial certainty. Ramifications for a bona fide trustee if an ostensibly valid trust can be declared a sham on the basis of the settlor's subjective intention alone.

Andrew Borrowdale (ed) Law of Trusts (online looseleaf ed, LexisNexis) at [1.1]; and Mark Maxwell Trusts: A Kiwi Sham? (Phantom Publishing, Hamilton, 2007) at 9, 19 and 25.

5 Official Assignee $v$ Wilson [2007] NZCA 122, [2008] 3 NZLR 45 [Wilson]. This was the first New Zealand appellate court decision to consider the sham concept in the trust context.

6 At [23].

7 Jessica Palmer "Dealing with the Emerging Popularity of Sham Trusts" [2007] NZ L Rev 81.

8 Matthew Conaglen "Sham Trusts" [2008] CLJ 176.

9 JE Penner The Law of Trusts (6th ed, Oxford University Press, Oxford, 2008) at 100; Phillip Pettit Equity and The Law of Trusts (Butterworths, London, 1993) at 50; Paolo Panico International Trust Law (Oxford University Press, Oxford, 2010) at 34; and Nicky Richardson "Sham Transactions" (2011) 7 New Zealand Family Law Journal 70.

10 Law Commission, above n 1, at 40.

11 Wilson, above $\mathrm{n}$ 5, at [26]-[65]. 
The Judges' reasoning has not convinced their critics. ${ }^{12}$ The precise elements that render a trust a sham remain a subject of debate amongst academics and practitioners. In view of the controversy surrounding the elements of a sham, the Law Commission suggested that the sham doctrine, as a means of analysing the validity of a trust, may not be the best approach. A better starting point would be a return to the certainty of intention requirement for a valid express trust. ${ }^{13}$ The Law Commission's suggestion mirrors Palmer's position and is preferred here.

This article's objective is to address aspects of the judgment in Wilson that were not discussed in Palmer's articles: first, to consider whether an express trust is a unilateral or bilateral transaction; second, to determine whether the history of trusts cases shows excluded evidence as having always been part of the objective intention inquiry; and third, to reflect how far legislative and policy factors have made foreign trust law distinct from New Zealand trust law. Finally, this article will expand on the test proposed by the Law Commission.

\section{WILSON AND THE SHAM DOCTRINE}

In Wilson, the Judges summarised the key features of the sham doctrine:

(1) Citing Snook $v$ London and West Riding Investment Ltd (Snook) ${ }^{14}$ (a hire purchase agreement case), an arrangement is a sham when it is designed to conceal the true nature of what is going on. ${ }^{15}$

(2) When both the settlor and trustee have a common (subjective) intention to mislead, the trust will be declared void ab initio. The lack of intention gives grounds to void the trust. ${ }^{16}$

(3) The settlor's subjective intention alone is insufficient to set aside an ostensibly (objective) valid trust.

The phrase "sham trust" is a misnomer. Sham and trust are mutually exclusive concepts. ${ }^{17}$ The word sham is meaningless apart from the context within which it arises. Sham is no more than a

12 Post-Wilson, both Jessica Palmer "What Makes a Trust a Sham" [2008] NZLJ 319, and Matthew Conaglen "Shams, Trusts and Mutual Intention" [2008] NZLJ 227 published papers criticising the joint judgments of O'Regan and Robertson JJ. Trust practitioners have also criticised the Judges' judgment. For example, Jim Guest "Is the Trust Fortress Strong Enough? ... Or 'One Door Shuts and another Door Opens'" (paper presented to the New Zealand Law Society Trusts Conference, June 2009) 125; and Anthony Grant "Sham Trusts and Constructive Trusts over Assets of a Trust" NZLawyer (online ed, New Zealand, 16 October 2009).

13 Law Commission, above n 1, at 59.

14 Snook v London and West Riding Investment Ltd [1967] 2 QB 786 (CA) [Snook].

15 Wilson, above n 5, at [26]; Paintin and Nottingham Ltd v Miller Gale and Winter [1971] NZLR 164 (CA) at 168; and Bateman Television Ltd v Coleridge Finance Co Ltd [1969] NZLR 794 (CA) at 813.

16 Nicola Peart "Trust Busting Looking through Trusts" (paper presented to the New Zealand Law Society Trusts Conference, June 2007) 174.

17 Panico, above n 9, at 34 
descriptive label attaching to a transaction which appears to be something that it is not. ${ }^{18}$ Therefore, on any given set of facts, there is either a trust or no trust and there is no such thing as a sham trust.

In trust law, a sham allegation questions the intention needed to form a trust. ${ }^{19}$ It is wellestablished that only the settlor's intention is relevant to the creation of a valid trust. Therefore, when the settlor has not manifested an intention to create a trust there is no trust. ${ }^{20} \mathrm{~A}$ trust is only a sham if the settlor lacks the intention to create a trust. ${ }^{21}$ Yet the Judges in Wilson insisted on a common intention requirement between the settlor and trustee to create a trust in pretence. The distinction drawn by the Judges reflects the academic debate between Conaglen and Palmer.

When addressing the issue of intention, Palmer observed that the common intention requirement had to be formulated in Snook because the case concerned a contract. Commonality of intention is essential to the creation of a contract, thus a common intention of a sham was appropriate. Palmer observed that Diplock LJ's dictum creates an obvious problem when applied to trusts. ${ }^{22}$ The common intention to create a sham is incorrect in the trust context because only the settlor's intention is required to create a valid trust. ${ }^{23}$ If a trustee disclaims the trustee office nomination, the trust subsists. ${ }^{24}$ The identification, and therefore the intention, of the trustee is not an essential prerequisite for its creation. ${ }^{25}$ Palmer's rationale is that one must determine what intention the law requires for the legally effective creation of the rights which is said to be the sham. The precise intention to be examined is critical. ${ }^{26}$ The inquiry should focus on whether the intention legally required for a trust to be effective was absent.

In the Judges' view, Palmer's argument mistakenly equates the essential form of a valid trust with that of a sham trust. ${ }^{27}$ This is because in the case of a sham, the intention goes to the non-

18 Penner, above n 9, at 172.

19 This was confirmed by the High Court in JEF v GJO [2012] NZHC 1021 at [69].

20 Tito $v$ Waddell (No 2) [1977] Ch 106.

21 Jessica Palmer "Controlling the Trust" (2011) 12 Otago L Rev 473; and GT Pagone "Sham Trusts" (paper presented to the Society of Trusts and Estate Practitioners Trusts Symposium, Adelaide, 9 March 2012).

22 Palmer, above n 12, at 320.

23 Also see Philip Laidlow "Shams" (July 2000) The Association of Corporate Trustees $<$ www.trustees.org.uk>.

24 Mallott $v$ Wilson [1903] 2 Ch 494.

25 Simon Gardner An Introduction to the Law of Trusts (3rd ed, Oxford University Press, Oxford, 2011) at 2 and 293; and Re Schebsman [1944] Ch 83 at 104.

26 Pagone, above n 21.

27 Wilson, above n 5, at [48]. 
creation of the trust. The Judges, approving Conaglen's article, ${ }^{28}$ gave two reasons for this distinction:

(1) Palmer mistakenly categorises all trusts as unilateral transactions, distinguishing them from consensual contractual agreements.

(2) The sham doctrine justifies the court stepping outside the orthodox construction of documents in order to ascertain the "truth of the matter" by reference to the excluded evidence of subjective intention and subsequent conduct. This justification is only permitted when the intention to mislead was shared by all parties to the alleged sham transaction.

\section{A Unilateral or Bilateral?}

The Judges divided trust transactions into two categories:

(1) A transaction is bilateral where the trust involves a trustee who is "separate and distinct" from the settlor. ${ }^{29}$ Contrary to Palmer's categorisation of all trust transactions as unilateral, most trust transactions are closer to the contractual paradigm, being bilateral and involving the intention and conscience of both settlor and trustee. ${ }^{30}$ Thus, the common intention requirement is appropriate for a bilateral trust transaction.

(2) A transaction is unilateral where the trust is settled by the same person. ${ }^{31}$ Here, the common intention requirement is precluded because there is no possibility that a mutual mental state will occur when the settlor and trustee are the same person. ${ }^{32}$

The bilateral categorisation creates immediate application issues for testamentary trusts. ${ }^{33}$ For a sham finding there must be a shared sham intention between the settlor and trustee. In a testamentary trust, the trustee will often have no knowledge of the nominated position until the settlor's death. Therefore, while most testamentary trusts are bilateral, because the trustee is "separate and distinct" from the settlor, it is impossible to speak of a mutual intention when the parties have never met. ${ }^{34}$

28 Conaglen, above $\mathrm{n} 8$.

29 Wilson, above n 5, at [41]; and Conaglen, above n 8, at 190.

30 Conaglen, above $\mathrm{n} 8$.

31 Wilson, above n 5, at [41].

32 John Langbein "The Contractarian Basis of the Law of Trusts" (1995) 105 Yale LJ 625 at 627.

33 At 636. Langbein proposed that testamentary trust is bilateral.

34 Maurizio Lupoi Trusts: A Comparative Study (Cambridge University Press, Cambridge, 2000) at 166, the author emphasised that testamentary trust cannot be bilateral. 
The unilateral and bilateral distinction is reflective of the wider academic debate on whether a trust is distinct from a contract. Throughout the Commonwealth jurisdictions, trusts and contract have long been recognised as distinct legal concepts. ${ }^{35}$ For example, trusts law recognises no unilateral and bilateral distinction in the principles relating to the formation of an express trust. ${ }^{36}$ Textbooks categorise contracts as bilateral and trusts as unilateral transactions considering only the settlor's intention. ${ }^{37}$

These long-standing principles have not deterred academics from arguing that a trust is essentially a contract. Conaglen and John Langbein emphasised that the majority of trusts are in fact bilateral agreements, or contracts, between settlor and trustee. ${ }^{38}$ Drawing analogies to Snook, Conaglen argued that the agreement between the settlor and trustee, being bilateral, can be declared a sham only with proof of common intent.

Langbein stresses that the origin of modern trust law is contractual in nature. ${ }^{39}$ Maurizio Lupoi partially agrees with Langbein's observation: ${ }^{40}$

Looking back over the history of trusts, the first examples were frequently cases of nominees, and were, therefore, in an area which today we define as contractual. Therefore, there exists, a contractual dynamic in trusts, and every theoretical approach must take account of this fact.

Langbein contends that the creation of modern trusts law is still contractual in nature: ${ }^{41}$

Trusts is a "deal" and that its characteristic aspect is not the legal event which precedes it (transfer of property to the trustee), but the (contractual) definition of the powers and responsibilities of the trustee. The "deal" between settlor and trustee that creates the trust, is voluntary. The trustee must voluntarily accept the trusteeship, that is, agree to serve under the terms of the trust; and those terms are wholly

35 James Wadham Willoughby's Misplaced Trust (2nd ed, Gostick Hall Publications, Cambridge, 2002) at 21.

36 Palmer, above n 12, at 320.

37 David Parker, Anthony Mellows and AJ Oakley Parker and Mellows: Modern Law of Trusts (18th ed, Sweet \& Maxwell, London, 2003) at 50; David Hayton and Oshley Marshall Hayton and Marshall Commentary and Cases on the Law of Trusts and Equitable Remedies (11th ed, Sweet \& Maxwell, London, 2001) at 158; and Geraint Thomas and Alastair Hudson The Law of Trusts (Oxford University Press, Oxford, 2004) at 42 .

38 Conaglen, above n 8; Langbein, above n 32, at 650 and 672; Frederic Maitland Equity (2nd ed, Cambridge University Press, London, 1936) at 54; and Chris Kelly and Greg Kelly "So You Want to be Trustee" (paper presented to the New Zealand Law Society Trusts Conference, June 2009) 25.

39 Langbein, above $\mathrm{n} 32$.

40 Lupoi, above n 34, at 162.

41 Langbein, above n 32, at 636 and 652. 
within the parties' autonomy. Thus, trusts like contract, is a consensual relationship. ${ }^{42}$ It is the intentions of both the settlor and trustee that are relevant to ascertaining the validity of the creation.

Langbein incorrectly categorises trust instruments defining the power and responsibilities of the trustee as contractual. ${ }^{43}$ The trustee's obligations as spelt out by the trust deed can be regarded as a contract between the settlor and trustee. Nevertheless, the common law of contract has never enforced the trustee's obligations. This has remained the province of Equity. ${ }^{44}$ Langbein also argues that the law should strive to implement the trust "deal" by permitting the settlor to enforce a trust, because the basis of the trustee's obligation is the trustee's promise to the settlor. ${ }^{45}$ Regrettably, he focuses on the wrong relationship. Today, trusts law focuses on the relationship between the trustee and beneficiary and not between the settlor and trustee. It is not the settlor who is entitled to enforce the agreement against the trustee, as would be the case if the agreement was contractual. ${ }^{46}$ Once a trust has been settled the settlor ceases to have any role, because all rights have been transferred to the trustee. ${ }^{47}$ If the settlor retains some powers, this is an incidental matter, which does not affect the focus of trusts law on the trustee and beneficiary relationship. ${ }^{48}$

Langbein journeys from the 14th century to today without deliberating on why the courts have not followed the original contractual source in modern trusts law. Langbein came to his conclusion because he ignored the existence of Equity. ${ }^{49}$ Today, it is well-established that a trust is not born out of an agreement (contract) between the settlor and trustee. ${ }^{50}$ With express inter vivos trusts, there are not one but two transactions which underlie the trust; the creation of the trust and the transfer of the rights to the trustee. ${ }^{51}$ The former, which actually gives life to the trust, is a unilateral act. ${ }^{52}$

42 Also see Kelly and Kelly, above n 38; and Shalson v Russo [2003] EWHC 1637, [2005] Ch 281 at 341 [Russo].

43 Langbein, above n 32, at 638; and Wadham, above n 35, at 31.

44 Penner, above n 9, at 18, 19 and 293; and Thomas and Hudson, above n 37, at 21.

45 Langbein, above n 32, at 664 and 672.

46 Penner, above n 9, at 39.

47 Lupoi, above n 34, at 195; Borrowdale, above n 4, at [A.15]; and Penner, above n 9, at 17 and 39.

48 Lupoi, above n 34, at 195.

49 Langbein, above n 32, at 166.

50 Langbein, above $\mathrm{n} 32$, at 4.

51 This distinction was confirmed by the Canadian tax court in Antle v The Queen (2009) TCC 465 at [40] [Antle]. See also Panico, above n 9, at 31; and Penner, above n 9, at 203.

52 Lupoi, above n 34, at 4 and 98; and Thomas and Hudson, above n 37, at 42. 
Non-acceptance by the nominated trustee has no effect on the creation of the trust. ${ }^{53}$ Acceptance of the trustee office does not turn the creation of a trust into a bilateral agreement. ${ }^{54}$

Lupoi stresses that the contractual context has receded in the path to Equity. Contractual connotations disappeared because the transfer of an estate is a unilateral transaction and the creation of rights to it in favour of third parties, whether in common law or Equity, is the transferor's business. However, Langbein emphasised that historical paradigm no longer conforms to modern reality. The contractarian account should become more prominent in light of the changes that have occurred in the character and function of the modern trust. ${ }^{55}$ Trust has changed its nature from a device for holding real property, often ancestral land, to a management regime for a portfolio of financial assets (for example stocks and bonds), which has intensified the contractual basis of the trust. ${ }^{56}$ The modern management trust has brought the settlor and trustee to actively negotiate over the terms of the trust deed before reaching a consensus. Thus, modern trusts may embody a contract about how property is to be deployed. ${ }^{57}$

The premise of Langbein's observation highlights the difference between the family and the commercial trust, ${ }^{58}$ namely that the latter springs from contract. ${ }^{59}$ The parties to that contract will have carefully designed its terms and conditions and setting up a trust is part of the contractual terms. ${ }^{60}$ Not even for the commercial trust is the legal nature of the trust affected. ${ }^{61}$ Further, in a family trust, it is the intention of the settlor alone that determines the deed terms. Today, that position is the same in all Commonwealth jurisdictions. ${ }^{62}$ The basis of family trust creation continues not to be contractual, irrespective of the fact that settlor and trustee may be different people.

Finally, the facts in Wilson do not match Langbein's "deal" observations. First, there was no evidence of negotiation between the settlor and trustees over the trust deed terms. The trust deed

53 Lupoi, above n 34, at 97.

54 Penner, above n 9, at 38.

55 At 638 .

56 At 643 .

57 At 671 .

58 Examples of commercial trusts are pension, investment, capital loan and unit trusts.

59 Donovan Waters "The Trust in a Changed and Yet Changing World" (2008) 15 JTCP 205 at 233.

60 At 228; and Lord Brown-Wilkinson "Equity, and its Relevance to Superannuation Schemes Today" (1992) 6 TLI 119 at 125 .

61 Lupoi, above n 34, at 166.

62 Waters, above n 59, at 223. 
appeared to be the standard document that the settlor's lawyer had presented to all of his clients. Second, unlike the United States and offshore trust jurisdictions, in New Zealand, the most common trust asset is the settlor's home, ${ }^{63}$ as was the case in Wilson. Further, unlike the trustees' roles of active investment and management in foreign jurisdictions, the trustees' role in New Zealand is simply to hold the trust property for succession. ${ }^{64}$ The make-up of the family trust in Wilson reflects the overall landscape of family trust in New Zealand. In other words, the family trust in New Zealand has not changed from its historical origin, ${ }^{65}$ and accordingly, only the settlor's intent is relevant to ascertaining the trust's validity.

\section{B Excluded Evidence}

The Judges in Wilson stated: ${ }^{66}$

While the objective appearance is the default determinant of a transaction's effect and substance, sham transactions are by definition transactional aberrations, and therefore require departure from the default principles of analysis. The common intention must be ascertained subjectively, in the departure from orthodox norms of construction so as to ascertain the true nature of the transaction.

The Judges' statement has academic support. According to Lewin on Trust,${ }^{67}$ when interpreting trust documents the foremost point is the objective meaning that the words of the document convey to the court, when considered as a whole in light of the surrounding circumstances. The settlor's subjective state of mind is inadmissible. ${ }^{68}$ Further, evidence of the parties' conduct after settlement is inadmissible to assist interpretation. However, such evidence is admissible when determining whether or not the settlement is a sham. ${ }^{69}$ The Judges' statements can be formulated into a two-step inquiry:

63 Chris Kelly "Supervision of Trustees: Enforcement or Problem Solving" (LLM Thesis, Victoria University of Wellington, 2009).

64 Waters, above n 59, at 226; Langbein, above n 32, at 638; and Graham Moffat Trusts Law (5th ed, Cambridge University Press, Cambridge, 2009) at 46

65 Langbein's "deal" categorisation was based on the changes in the character and function of the modern trust. Given the typical New Zealand family trust has not shifted away from its historical character and function, Langbein's contractual observations based on offshore trust development is incompatible with New Zealand trust development.

66 Wilson, above n 5, at [50].

67 John Mowbray and others Lewin on Trusts (18th ed, Sweet \& Maxwell, London, 2008) at 199.

68 At 200 .

69 AG Securities v Vaughan [1990] 1 AC 417 (HL). 
(1) Did the settlor manifest an objective certainty of intention? Evidence is confined to the trust deed itself; ${ }^{70}$ and

(2) If an objective intention has been manifested, a sham inquiry will be undertaken. Evidence expands to subjective intention and post-settlement conduct. ${ }^{71}$

Post-Wilson, this two-step process was followed by the High Court in JEF v GJO. ${ }^{72}$ Here, Duffy $\mathrm{J}$ declared that drawing up a trust deed detailing the powers of the trustees is more than enough to evidence the settlor's objective intention to create a trust. ${ }^{73}$ Once an objective intention is clearly manifested, the sham trust argument is the only way to assert that the trust is void for a lack of intent. ${ }^{74}$ Duffy J's statements embody the current judicial consensus that having a trust deed is sufficient evidence of an objective intention. Subjective intention and subsequent conduct cannot be referred to in the absence of an allegation of a sham.

Both steps target the settlor's lack of intention to create a trust. This raises the question: are two separate claims needed to achieve the same judicial declaration, namely, no trust, when the only difference between the two is evidential? If courts of Equity have always examined the otherwise excluded evidence without "stepping outside" the objective intention inquiry, this two-step inquiry is incorrect.

\section{Subjective intention}

Conaglen contended that sham is a separate doctrine because it allows the court to consider otherwise excluded evidence under the contractual construction process to ascertain the truth of the matter. ${ }^{75}$ This position is disputed amongst contract experts. ${ }^{76}$ Commentators claim that Diplock LJ's unease with the idea of the sham doctrine is born from the fact that the doctrine does not exist in its own right, but rather reflects the normal issues surrounding construction of documents. For example, Susan Bright argues that "the Snook definition is easy to reconcile with contractual theory"

70 When the settlor did not genuinely intend to create a trust, the usual objective intention inference drawn from the trust deed will suggest a genuine trust intention on the settlor's part.

71 See also Conaglen, above n 8, at 182; and Mackinnon v Regent Trust Company Limited and Eight others [2005] JLR 198 at 203 [Mackinnon].

$72 J E F v G J O$, above n 19.

73 At [61].

74 At [62].

75 Conaglen, above $\mathrm{n} 8$.

76 S Bright "Beyond Sham and into Pretence" (1991) 11 OJLS 136; and B McFarlane and E Simpson "Tackling Avoidance" in J Getzler (ed) Rationalizing Property, Equity and Trusts (LexisNexis, London, 2003). 
as it merely "gives effect to the parties' intentions". ${ }^{77}$ McFarlane and Simpson have similarly argued that: ${ }^{78}$

There is no separate set of criteria justifying the finding of a sham because the court's task is simply to ascertain the genuine intentions of the party or parties in circumstances where those intentions are relevant.

Conaglen conceded that if sham is not a separate doctrine, there is no need to discuss its application to trusts. ${ }^{79}$ These disagreements should alert courts to the need to take heed before adopting a doubted concept from another legal field.

Is all subjective evidence excluded under the intention inquiry? Conaglen cited support from Lord Millet's judgment in Twinsectra Ltd v Yardley: ${ }^{80}$

A settlor must possess the necessary intention to create a trust, but his subjective intentions are irrelevant. If he enters into arrangements which have the effect of creating a trust, it is not necessary that he should appreciate that they do so, it is sufficient that he intends to enter into them.

This passage requires careful consideration. Contrary to Conaglen's position, Lord Millet is not advocating a wholesale exclusion of the settlor's subjective intention under the objective intention inquiry. Instead, "mistake" is the only type of a settlor's subjective intention that is excluded. A mistake is where the settlor claims he or she was not aware that their actions or words have created a trust. ${ }^{81}$ Where the settlor had no genuine intent to create a trust, the settlor is aware that their actions or words have created a trust in pretence only. Moreover, his Lordship emphasised the need for a settlor to "possess the necessary intention to create a trust". ${ }^{82}$ The question then becomes: have previous courts taken account of the settlor's subjective intentions, excluding mistake, under the objective intention inquiry? If so, the evidential basis of the intention inquiry has never been confined to the trust deed. Moreover, the otherwise excluded evidence of subjective intention is merely an evidential factor under the intention test.

77 S Bright, above n 76, at 140 .

78 B McFarlane and E Simpson, above n 76, at 139.

79 Conaglen, above $\mathrm{n} 8$, at 179

80 Twinsectra Ltd $v$ Yardley [2002] UKHL 12, [2002] 2 AC 164 at [71]. This passage was also cited in Re Esteem Settlement Grupo Torras SA v Al Sabah [2003] JLR 188 at 217 [Sabah]. The opposite conclusion was reached in Sabah at 218.

81 Thomas and Hudson, above n 37, at 66; and G Dal Pont and D Chalmers Equity and Trusts in Australia (3rd ed, Lawbook Co, Pyrmont (NSW), 2004) at 447.

82 Lord Millet's statement was echoed in the case of Re Armstrong [1960] VR 202. 
Before the language of sham entered into the realm of trust law, the High Court of Australia already favoured a subjective approach to the question of intention to create a trust. The Court upheld the proposition that a subjective intention to create a trust was decisive, and trumps a trust that was constituted ostensibly without "stepping outside" the intention inquiry. The majority in Commissioner of Stamp Duties (Qld) v Jolliffe (Jolliffe) stated: ${ }^{83}$

We know of no authority and none was cited which would justify us in deciding that by using any form of words a trust can be created contrary to the settlor's real intention. It is essential to the trust creation, that there should be an intention of creating a trust. Therefore if upon consideration of all the circumstances the Court reached the opinion that the settlor did not intend to create a trust, the Court will not impute a trust where none in fact was contemplated.

In 2008, the High Court of Australia supported the majority position in Jolliffe as good law in Australia. ${ }^{84}$ This judicial approval has not silenced critics of Jolliffe. Critics have argued that Jolliffe is not good law because the language of the trust deed is imperative and is the conclusive evidence for intention. ${ }^{85}$ Therefore the settlor's subjective intention plays no role in ascertaining intention. ${ }^{86}$ The criticism of Jolliffe originates from the wider concern that a subjective approach to intention generally infringes too greatly on the "parol evidence" rule. ${ }^{87}$ This is a contract law rule which prevents a party to a written contract from presenting extrinsic evidence that contradicts or alters the written terms of the contract. ${ }^{88}$ The relevance of the rule to intention was examined in the Canadian tax case of Antle $v$ The Queen (Antle). In that case, Miller J unequivocally declared that for the certainty of intention inquiry, the "parol evidence" rule is irrelevant. ${ }^{89}$ What must be determined is whether there is an intention to create a trust? This is not a question of contractual interpretation. A trust is a property relationship, ${ }^{90}$ not a contract for consideration. To suggest that only the words in the documents can be relied upon to define the relationship is presuming that the arrangement is a

83 Commissioner of Stamp Duties (Qld) v Jolliffe (1920) 28 CLR 178 at 181 [Jolliffe]. This passage was included in all subsequent editions of Lewin on Trusts until John Mowbray Lewin on Trusts (17th ed, Sweet \& Maxwell, London, 2000) at [4-23] where Mowbray stated that the minority judgment in Jolliffe is now preferred in England. This article favours the majority judgment in Jolliffe.

84 Raftland Pty Ltd v Federal Commissioner of Taxation [2008] HCA 21, (2008) 238 CLR 516 at 535.

85 "Jolliffe's Case and Subsequent Decisions" (2009) Monash University <law.monash.edu.au>.

86 This argument was raised in Antle, above n 51, at [42].

87 The parol evidence rule was a reason why the minority in Jolliffe disagreed with the majority.

88 Owens v Lofthouse [2007] FCA 1968 at 63.

89 Antle, above n 51, at [44].

90 Also see $B v X$ [2011] 2 NZLR 405 (HC); M Leeming "What is a Trust?" (2008) 31 Aust Bar Rev 211; and Jessica Palmer and Simon Weil "Beneficiaries Rights the More you Get the Less you Have?" (paper presented to the New Zealand Law Society Trusts Conference, June 2009) 77. 
negotiated contract between two parties, where each side has provided consideration to obtain a mutually acceptable deal. ${ }^{91}$ Miller J emphasised that the search for intention should not be limited to the trust deed alone and subsequent conduct is relevant to the absence of the settlor's intention to create a trust. Miller J's rejection of the view that trust and contract are the same contradicts the Judges' argument in Wilson that construction principles applying to contract are equally applicable to trusts. This is because the Judges in Wilson failed to consider the role of Equity. The intention inquiry is underlined by the maxim "Equity looks into intent not form". ${ }^{92}$ Moving away from the confines of the trust deed would be consistent with the doctrinal understanding that the settlor will not be saved by the language of the trust deed itself, if the settlor did not intend to create a trust. ${ }^{93}$

Jolliffe was not considered by the Judges in Wilson. Further, Antle was heard after Wilson. Nevertheless, it is difficult to see what reasons, if any, could have been offered by the Judges for rejecting these authoritative statements. The quoted paragraph from Jolliffe mirrors Bright's view: the task is simply to ascertain the relevant party's genuine intention. Here, the settlor's intention exclusively. In respect of the Judges' two-step inquiry, a more accurate legal statement on the evidential relevance of the settlor's subjective intention under the intention inquiry should be:

The evidential basis for the intention inquiry is not confined to the trust deed itself. The settlor's subjective intention of never disposing his or her equitable interest will override any objective intention derived from the trust deed itself.

What factors would evidence the settlor's subjective intention? In previous sham trust cases, there has been very little, if anything, in the trust deed to indicate the settlor's non-intent to create the trust at inception. ${ }^{94}$ Intentions were often inferred from the settlor's behaviour and modus operandi $^{95}$ of the trust. For example:

(1) In Rahman v Chase Bank (CI) Trust Co Ltd (Rahman), ${ }^{96}$ the settlor referred to the trust as "his asset". The trustee had no administrative autonomy. The settlor performed the trustee's duties. For example, under the trust deed, the trustee should have appointed the investment advisor. The settlor not only appointed the advisor, he also distributed trust funds to himself on a regular basis and merely notified the trustee of his decisions from time to time.

91 Antle, above n 51, at [44].

92 AJ Oakley Parker and Mellows: The Modern Law of Trusts (6th ed, Sweet \& Maxwell, London, 1994) at 90 .

93 Tito v Waddell (No 2), above n 20; Re Hamilton [1895] 2 Ch 370; Re Kayford (In Liquidation) [1975] 1 WLR 279 (Ch); and JG Riddall The Law of Trusts (5th ed, Butterworths, London, 1996) at 30.

94 Begum v Ali FC Auckland FAM-2001-004-866, 12 November 2004.

95 Translated into English means: "method of operation".

96 Rahman, above n 2 
(2) In Begum v Ali (Begum), ${ }^{97}$ property was transferred to the trust at significantly below its real value. Following the trust formation, there was a total lack of formality relating to the trust's affairs. The settlor continued to act solely with regard to the trust property without reference to the trustees. The trustees' involvement had been limited to expressions of concern when, from time to time, they had been advised of the outstanding mortgage payments. Finally, the settlor occupied the trust property as a tenant with no tenancy agreement and a casual arrangement as to whether and when rent was to be paid.

(3) In Midland Bank plc $v$ Wyatt (Wyatt), ${ }^{98}$ the settlor created an impression to third parties that he remained the trust property's beneficial owner. For example, the mortgagee and business partner believed that the settlor owned the trust property long after the property was transferred to the trust. Further, shortly after the trust declaration, the settlor offered the trust property as security for a personal loan.

This case law highlights that direct evidence of an intention to create a sham trust will seldom be available. This judicial pattern also highlights the problematic nature of the common intention requirement. A common intention to "mislead", in the sense of some kind of agreement between the parties, is required. ${ }^{99}$ This does not conform to reality. In all previous sham cases, the common indicia of the "misleading" intention were trustees not exercising their fiduciary duties and the settlor's intent of not giving up beneficial interest as opposed to explicitly reaching an agreement to create a façade. Having highlighted that subjective intention is not excluded evidence under the objective intention inquiry, this article will now examine whether subsequent conduct also falls within this category. If so, then sham concerns an evidential factor relating to the intention required for a valid trust, not a separate doctrine.

\section{Subsequent conduct}

Nicola Peart observed that in practical terms the evidential basis for the intention and sham inquiry will be the same. ${ }^{100}$ Under both inquiries, the subsequent conduct of settlor and trustee is relevant. This relevance may shed light on the intention at the time of settlement. Peart's observation is supported by case law, where no sham allegation arose: ${ }^{101}$

97 Begum v Ali, above n 94.

98 Midland Bank plc v Wyatt [1997] 1 BCLC 242 [Wyatt].

99 This requirement was emphasised in Russo, above n 42, at [190].

100 Peart, above n 4, at 66.

101 Note in Hyhonie Holdings Pty Ltd v Leroy [2003] NSWSC 624 [Hyhonie], a sham allegation was raised by the defendant in passing. Nevertheless, after examining subsequent conduct, the New South Wales Supreme Court concluded that the settlor never had intention to create a trust therefore the Court did not need to discuss the sham allegation; and also see Gaskell v Gaskell (1828) 2 Y \& J 502, 148 ER 1017 (Exch). 
(1) In Paul v Constance, ${ }^{102}$ the subsequent conduct of depositing the joint "bingo" winnings into an account under the settlor's name only, while withdrawals from that account were for joint purposes and the settlor's relationship with the plaintiff during the last few years of his life persuaded the Court to conclude that the repeated words of "the money is as much yours as mine" manifested an intention to create a trust.

(2) In Starr v Starr, ${ }^{103}$ express declarations of trust over several bank accounts were declared void after evidence proved that the settlor continued to operate these accounts as his own. When the settlor required money personally, he withdrew from the trust accounts. The settlor closed the two trust accounts after transferring the remaining funds from those accounts into his own personal bank account.

(3) In Hyhonie Holdings Pty $v$ Leroy, ${ }^{104}$ the declaration of trust was found to have no effect where the settlor continued to exercise personal dominion over the trust property without any reference to the trust. No documentation other than the trust instrument itself indicated that the trust was ever carried into effect.

James Wadham's Willoughby's Misplaced Trust stated the same view as Peart. ${ }^{105}$ It highlighted the fact that increasingly the settlor's intent under the certainty of intention inquiry is more readily drawn from the adverse inference of subsequent conduct, than from the words of the trust deed alone. Subsequent conduct has become the evidentiary cornerstone of the intention inquiry. These observations were not considered by the Judges in Wilson. Moreover, it also answers the question posed at the beginning of this article: is a separate sham claim necessary when the only difference between the certainty of intention and sham claim is one of evidential foundation? The answer is no. Before the word sham infiltrated trust law, when ascertaining settlor's intention, the settlor's subjective intention and the post-settlement conduct of the settlor and trustee were always part of the inquiry. Moreover, the excluded evidence of the sham intention is the same evidence that courts have traditionally relied upon for drawing the inference that the settlor did not intend to create a trust.

For example, in Rahman, the settlor's extensive rights reserved under the deed and his continuous treatment of the asset as his own are typical indicia that the settlor had no intention to dispose of any beneficial interest in the trust property. In Begum, Judge O'Donovan upheld a sham allegation on the basis that "the trustees were at all times aware that it was never intended that they should become the property owner and ... that the [settlor] ... retain his interest therein". The basis

102 Paulv Constance [1977] 1 WLR 527 (CA).

103 Starr v Starr (1935) SASR 263 (SC).

104 Hyhonie, above n 101.

105 Wadham, above n 35, at 31 . 
of this sham finding can be easily reworded into a finding of no intention because at no time did the settlor have a genuine intention to dispose of his beneficial interest.

In conclusion, a separate sham claim is unnecessary because the excluded evidence can be dealt with under the certainty of intention requirement. As was proposed by the Law Commission, courts should return to the doctrinal intention test. That is, did the settlor manifest an intention to dispose of his or her beneficial interest in the trust property? This test had been universally accepted by Commonwealth jurisdictions for centuries before the word sham undesirably crept into trust law.

\section{FOREIGN CASES}

\section{A General}

Palmer concedes that the weight of overseas judicial authority supports the common intention requirement. That concession was another reason why the Judges in Wilson reached their conclusion. ${ }^{106}$ The starting point in any comparative law analysis is that overseas cases are not binding on New Zealand courts. ${ }^{107}$ Therefore, a careful analysis of the legislative and policy frameworks that influenced the foreign judges' preference for the common intention requirement is required before being adopted by New Zealand courts. No such exercise was undertaken in Wilson.

\section{$B$ Wyatt}

The earliest reported English case in which the sham concept was considered in detail in relation to trust law was Wyatt. ${ }^{108} \mathrm{Mr}$ and Mrs Wyatt declared themselves trustees to hold the proceeds of an asset sale on trust for Mrs Wyatt and the couple's daughters. The declaration document contained the power for Mr and Mrs Wyatt as the trustees to deal with the property as if they were the absolute owners. The Court found no difficulty in applying Snook to sham transactions generally. Nevertheless, it was surprising that the Judges in Wilson ${ }^{109}$ interpreted Wyatt as an authority for the common intention requirement. ${ }^{110}$ The Judges held that Wyatt broadened the scope of trustee intention to include recklessness or ignorance and treated trustee intention as relevant. ${ }^{111}$ Judge Young in Wyatt made the statements that allegedly broadened the scope of trustee intention in the following context: ${ }^{12}$

106 Wilson, above n 5, at [41].

107 Nicky Richardson "Sham and Alter Ego Trusts in New Zealand" (2009) 23 Tru LJ 130.

108 Wyatt, above n 98.

109 Wilson, above n 5, at [38].

110 See also Conaglen, above n 12.

111 This view was shared by the Royal Court of Jersey in Sabah, above n 80, at 223; and A v A and St George Trustees Limited [2007] EWHC 99 (Fam) at [52].

112 Wyatt, above n 98, at 245 . 
I do not understand Diplock LJ's observations regarding the requirement that all parties to the sham trust must have a common intention to be a necessary requirement in respect of all sham transactions. A sham transaction will still remain a sham even if one of the parties to it merely went along with the "shammer" not even knowing or caring about what he or she was signing.

Those statements were made in response to an argument that a finding of sham under Diplock LJ's observation could not be made due to the lack of a common "shamming" intention on Mrs Wyatt's part as she appeared to be unaware of the trust declaration she had signed with her husband. Therefore, Judge Young articulated those statements with a focus on Mrs Wyatt's intention as the settlor, not the trustee, at the time of the purported trust declaration. Finally, Judge Young held that the trust was a sham because, at the time the trust deed was executed, the settlor did not intend to vest beneficial interests in the beneficiaries. No reference to common intent was made in the Judge's final conclusion. Further, based on the evidential foundation of the sham finding, ${ }^{113}$ it is apparent that Judge Young focused the sham inquiry solely on the settlor's intention and not the common intention of the settlor and trustee. ${ }^{114}$

\section{Rahman}

Before Wyatt, Rahman, ${ }^{115}$ a Royal Jersey Court decision, was often cited as the leading sham trust case in the world. The Court concentrated on the Jersey ${ }^{116}$ customary maxim "donner et retenir ne vaut"117 and its application to trusts. ${ }^{118}$ Thus, the main focus of the decision was not a definition of sham trust. Rather, it pointed to certain factual circumstances, where the trust would be recognised as a sham. Indeed, Rahman's settlement was held to be a sham because the settlor exercised dominion and control over the trustee, which appear to be civil law categories consistent with the legal background against which the sham finding was made, namely the French customary law in force at the time in Jersey and not the common law certainty of intention. ${ }^{119}$ The maxim that directed the Court in Rahman to its sham declaration has never been part of New Zealand trust law. No attention was paid to this critical factor in Wilson. Further, notwithstanding the Jersey Court's incidental remarks on sham, the Judges in Wilson cited Rahman as a case supporting the common

113 The evidential foundation for Judge Young's conclusion was the settlor's subsequent conducts after the trust deed execution.

114 For a different reason, Palmer, above n 4, at 339 also disagrees with O'Regan and Robertson JJ's interpretation of Wyatt.

115 Rahman, above n 2.

116 Jersey's legal system is not at all common law. Instead, it is the product of the customary law of the old Duchy of Normandy.

117 Translated into English means: "To give and to keep has no effect".

118 Rahman, above n 2, at 113.

119 Panico, above n 9, at 40. 
intention requirement. ${ }^{120}$ This conclusion is unjustified. The common intention requirement was not discussed in Rahman. Moreover, like Wyatt, the Court in Rahman overwhelmingly concentrated on the settlor's action as the evidential cornerstone for their sham conclusion. The trustee's action was merely a consideration in the overall conclusion. The Court never elevated the trustee's intention to the height of the common intention requirement, as was suggested in Wilson. A judicial pattern emerged after Wyatt and Rahman. That is, trusts will be declared a sham based on the settlor's intention alone. ${ }^{121}$

\section{Re Esteem}

The first reported case where the unilateral or bilateral intention on the part of the settlor and trustee argument was raised was in Re Esteem Settlement Grupo Torras SA v Al Sabah (Sabah). ${ }^{122}$ The creditors' unilateral sham argument is reflected in the later Palmer article ${ }^{123}$ as well as contending that Rahman was a unilateral sham case. ${ }^{124}$ The Judges in Sabah were of the view that there was insufficient evidence to support the contention that the Court in Rahman considered that a unilateral sham was sufficient. ${ }^{125}$ The Court concluded that Rahman was of no assistance to the unilateral and bilateral sham issue ${ }^{126}$ because, although Snook was cited, this issue was not raised or considered in Rahman. ${ }^{127}$ The only other authority cited on this issue was Chase Manhattan Equities Ltd v Goodman and others (Goodman). ${ }^{128}$ As in Rahman, while Snook was cited, the intention issue was not argued and consequently not commented on by the Court in Goodman. ${ }^{129}$ Considering Rahman as irrelevant because the intention issue was never addressed in that case, Goodman would also be an irrelevant authority. Surprisingly, Goodman was cited in Sabah as the authority for the common intention requirement. ${ }^{130}$ No obvious reason was offered for this preference.

120 Wilson, above n 5, at [31].

121 This is often referred to as unilateral sham because a trust is declared a sham based on the settlor's intention alone.

122 Sabah, above n 80.

123 Sabah, above n 80, at 214.

124 At 215 .

125 At 221. The opposite conclusion was reached in the previous paragraph of this article.

126 At 221. This conclusion was cited in the subsequent English sham trust case of Russo, above n 42, at [188].

127 Sabah, above n 80, at 220.

128 Chase Manhattan Equities Ltd v Goodman and others [1991] BCLC 897 [Goodman].

129 Sabah, above n 80, at 215.

130 At 215. 
The Jersey Court's preference for Goodman could have been motivated by Jersey's prolific trust industry. Jersey's trust law is drafted with the aim of attracting wealthy foreigners. Jersey's trust law accommodates foreigners' desire to settle trusts there (for tax and succession reasons) without giving up control over the trust property. New Zealand's trust law is not predominantly driven by such an objective. Paolo Panico emphasised that Rahman's settlement was held to be "a sham on the facts" because the settlor had retained and exercised control over the trust. ${ }^{131}$ For this reason, Rahman prompted a widespread concern with the issue of shams in the Jersey trust industry. ${ }^{132}$ Had the Court in Sabah preferred the sham finding in Rahman based on the settlor's control alone, it would have undermined the policy aim behind Jersey's trust law. Wealthy foreigners wanting to retain control over the trust property would take their money elsewhere. In 2005, the Jersey Court of Appeal in Mackinnon v Regent Trust Company Limited confirmed that the incorrect sham finding in Rahman was the key catalyst for the common intention requirement. ${ }^{133}$ However, in New Zealand, the control issue has traditionally been dealt with by the certainty of intention requirement without reference to sham. ${ }^{134}$ Therefore, from a comparative law perspective, the declaration of no trust in Rahman on the basis of settlor control is more consistent with New Zealand trust law than a similar declaration upheld on the basis of common intention formulated in Sabah.

\section{E Jersey's Trust Legislation}

The statutory framework that forms the backdrop to Jersey's trust law is another reason why New Zealand courts should not follow Jersey cases. ${ }^{135}$ Jersey, like many other international trust jurisdictions, has legislation distinct from traditional Commonwealth law countries such as New Zealand. ${ }^{136}$ The enhanced reserve powers conferred on the settlor under Jersey's legislation point towards an evolution of trust law along contractual terms, verging on a form of agency arrangement. ${ }^{137}$ Leading trusts textbooks ${ }^{138}$ stress the distinction between agency, contract and

131 Panico, above $\mathrm{n} 9$, at 40 .

132 Rose Marie and Belle Antoine "The Offshore Trust: a Catalyst for Development" (2007) 14 JFC 264.

133 Mackinnon, above n 71, at 206 and 207.

134 See the next Part of this article for a detailed analysis on the issue of control; and also see Donovan Waters "Settlor Control - What Kind of Problem is It?" (2009) 15 Trusts and Trustees 12.

135 The first Jersey trust legislation was the Trusts (Jersey) Law 1984 which came into force on 23 March 1984.

136 Panico, above n 9, at 3; Waters, above n 59, at 226; and Law Commission Review of Trust Law in NZ Introductory Issue Paper (NZLC IP19, 2010) at 20.

137 Panico, above n 9, at 3.

138 Noel Kelly, Chris Kelly and Greg Kelly Garrow and Kelly Law of Trusts and Trustees (6th ed, LexisNexis, Wellington, 2005) at [1.6.2]. 
trust. An example of the emerging contractual element in Jersey legislation is the $\operatorname{articles}^{139}$ that overrode the Court's finding of sham in Rahman. The finding in that case was based on the settlor's control over the rights that were not effectively passed to the trustee: that is, without entrusting. For there to be a trust there must be entrusting of the right in favour of the trustee. Therefore entrusting equates to a loss of all entitlement by the settlor. ${ }^{140}$ Lupoi observes that, prima facie, these legislative articles suggest that the Jersey legislature intended to make trusts valid notwithstanding a lack of entrusting. ${ }^{141}$ If Lupoi is correct, this is a sign that a contractual element is emerging in offshore trust practice.

Jersey's reserved power legislation enables the settlor to retain an active role and reserve beneficial interest without impairing a trust's validity. ${ }^{142} \mathrm{New}$ Zealand trust legislation does not determine trust validity. Moreover, Panico warned that a trust with extensive retention of powers to the settlor is not immune from risks outside Jersey. ${ }^{143}$ One risk is that such retention of power might be taken as evidence of a settlor's lack of intention to create a trust. ${ }^{144}$

Powers such as powers of revocation and appointment are not by themselves objectionable. ${ }^{145}$ However, when those powers are retained by the settlor, an issue arises as to whether such a trust is actually valid. ${ }^{146}$ In New Zealand, the more power that is retained by the settlor the easier it is for a court to categorise the relationship as one involving a nominee or agent. For example, in Equiticorp Industries Group Ltd (In Statutory Management) v The Crown (No 47), ${ }^{147}$ the power reserved in the trust deed included the power of appointment and removal of any trustee and beneficiaries. The settlor's consent was required for varying the deed's term, termination of the trust and distribution of trust property to beneficiaries. Smellie $\mathrm{J}$ held that these reserve powers gave the settlor a significant degree of control over the trustee's powers and therefore the relationship was one of nominee. All the reserve powers mentioned in Equiticorp are listed in Jersey's trust legislation. ${ }^{148}$ Under Jersey's

139 The relevant articles are art 8A of the Trusts (Amendment) (Jersey) Law 1989 and art 9 of the Trusts (Amendment No 4) (Jersey) Law 2006. This provision was the necessary complement to the 'reserved power legislation' introduced under the same Trusts (Amendment No 4) (Jersey) Law 2006 as art 9A.

140 Lupoi, above n 34, at 197.

141 At 265.

142 Trust (Jersey) Law 1984, arts 9A and 9A(1)(a).

143 Panico, above n 9, at 64.

144 At 70.

145 Panico, above n 9, at 63.

146 At 64.

147 Equiticorp Industries Group Ltd (In Statutory Management) v The Crown (No 47) [1998] 2 NZLR 481 (HC) [Equiticorp].

148 Trust (Jersey) Law 1984, arts 9A(2)(a), 9A(2)(e) and 9A(2)(h). 
legislation, Smellie J's finding would be explicitly forbidden because those reserved powers will not affect trust validity. Therefore, the foundations that normally evidence the settlor's intention not to create a trust (for example the incompatibility between the settlor's extensive reserve powers and trust) have been legislated away.

The discussion above illustrates the overall incompatibility between Jersey and New Zealand trust law. First, relationships that have been traditionally recognised as contract, nominee or agency in New Zealand are legislatively recognised as trusts in Jersey. There is no evidence pointing to the conclusion that the New Zealand trusts model is now being considered as a contractual, agency or nominee relationship. Second, the express reference to "beneficial interest" in the Jersey legislation is indisputable evidence of the Jersey legislature's intention to prevent any challenges to a trust's validity based on the doctrinal Equity rule: the greater the beneficial interest retained in the trust property by the settlor, the easier it is for the court to draw the inference that the settlor did not intend to create a trust. ${ }^{149}$ Given that no similar legislative framework exists in New Zealand, New Zealand courts should not follow Jersey cases. Moreover, following the Law Commission's recommendation, a return to the certainty of intention requirement should be preferred because it is more compatible with New Zealand's non-legislated trust law framework.

\section{IV "CORRECT" LAW}

In light of the above discussions, it is submitted that a more accurate statement of law would be:

(a) The question of whether a trust exists should be determined solely by the doctrinal certainty of intention test. This is a question of fact.

(b) The settlor must manifest an intention to dispose of his or her property. ${ }^{150}$ If available, the following evidentiary factors are relevant:

(a) The extent of the settlor's power over the trustee:

(1) Conceptually, once a settlor has transferred property to a trustee he or she has no right left vis-à-vis such property. ${ }^{151}$ In practice, the trustees may well consider the settlor's views, but they must exercise their own independent judgement. If the trustee automatically follows the settlor's instructions without exercising their own discretion, the decision will be void. ${ }^{152}$ Further, the settlor has no power in regard to the trust property once the power is vested in the trustee.

149 Lupoi, above n 34, at 101 and 135; and Wadham, above n 35, at 75.

150 Richards v Delbridge (1874) LR 18 Eq 11 (Ch); Hughes v Stubbs (1842) 1 Hare 476 at 479, 66 ER 1119 (Ch) at 1120; and Re W (Ex Parte Orders) [2000] 2 FLR 927 at 938.

151 Bradshaw v University College [1988] 1 WLR 190 (Ch); David Hayton The Law of Trusts: Fundamental Principles of Law (Sweet \& Maxwell, London, 1989) at 107; and David Hayton The Law of Trusts (4th ed, Sweet \& Maxwell, London, 2003) at 78 and 135.

152 Turner v Turner [1984] Ch 100; and Maxwell, above n 4, at 9 and 45. 
These behaviours will add weight to the allegation that the settlor had no intention to create the trust. ${ }^{153}$

(2) Trust is a transfer of rights. The unilateral nature of trusts means that the settlor may retain certain rights in respect to the trust property. The withholding of rights (for example to remove trustees ${ }^{154}$ or add beneficiaries) falls within the parameters of every unilateral method of disposition. ${ }^{155}$ Its limitations lie in the effectiveness of the grant. ${ }^{156}$ Therefore, the more rights that are retained by the settlor, the easier it is to draw the inference that the settlor did not intend to create a trust. ${ }^{157}$ It is ultimately a question of degree. ${ }^{158}$ For example, the settlor's reserve powers of revocability, that the trustees must follow the settlor's directions as to investments and distributions of property to beneficiaries, are powers more akin to an agency than a trust arrangement.

(a) Subject to the mistake exception, the settlor's subjective intention is admissible; and

(b) Post-settlement conduct of the settlor and trustee may either evidence or contradict the trust deed. Have the trustee duties been performed properly? ${ }^{159}$ The list of duties includes: ${ }^{160}$

(1) Administer the trust honestly and impartially for the benefit of all the beneficiaries. ${ }^{161}$

(2) Account strictly to the beneficiaries including distributing income and capital in accordance with the trust's terms. ${ }^{162}$

(3) Hold and attend regular trustees' meeting (at least annually). ${ }^{163}$

153 Panico, above n 9, at 14.

154 This power was approved in London \& County Banking Co v Goddard [1897] 1 Ch 642.

155 Waters, above n 134.

156 Lupoi, above n 34, at 164; and Denham Martin "Tax Issues an Update" (paper presented to the New Zealand Law Society Trusts Conference, June 2009) 177.

157 Mark Gillen and Donovan Waters (eds) Water's Law of Trusts in Canada (3rd ed, Thomson Carswell, Toronto, 2005) at 62; Lupoi, above n 34, at 101 and 135; and Wadham, above n 35, at 75.

158 Waters, above n 134.

159 Penner, above n 9, at 22; and Ross Holmes Sham Trusts (Imprint Pacific Trusts, Auckland, 1999) at 16.

160 For an exhaustive list of trustee's duties see: Maxwell, above n 4, at ch 5; Wadham, above n 35, at 85; and Hayton The Law of Trusts: Fundamental Principles of Law, above n 151, at 111.

161 Re Tempest (1865-1866) LR 1 Ch App 485 at 487; and Re Mulligan (deceased) [1998] 1 NZLR 481 (HC).

162 Holmes, above n 159, at [1.3].

163 Dundee Hospital [1952] 1 All ER 896 at 900. 
(4) Keep proper records. This includes agreement for sale and purchase, minute books, resolutions and annual financial accounts. ${ }^{164}$

(5) Consider the exercise of their powers. ${ }^{165}$

(6) Adhere strictly to the trust's terms. ${ }^{166}$

(7) Act personally and jointly when there is more than one trustee. ${ }^{167}$

(8) Act at all times in the best interests of the beneficiaries. ${ }^{168}$

\section{APPLYING THE "CORRECT LAW" TO WILSON}

The Judges in Wilson held that the assignee, who stood in the settlor of the family trust Reynolds' shoes, had no legal standing to make a sham claim because "... there could be no justification in allowing Reynolds to seek relief ... effectively for his own benefit". 169 Hayton correctly argued that the Assignee did in fact have a legal standing to sue: a sham finding would have been for the benefit of Reynolds' creditors and not for Reynolds' own benefit. ${ }^{170}$

The crucial issue is whether the trust deed, the settlor's subjective intention and subsequent conduct are, together, enough to establish that Reynolds intended to create a trust. The Judges in Wilson agreed that the activities of the trustees invited challenge. ${ }^{171}$ With the trust deed not publicly available, this article accepts the High Court's finding that the trust deed in Wilson, largely in standard form, evidenced an objective intention to create a trust. ${ }^{172}$ There was no direct evidence on Reynolds' subjective intention. Therefore the settlor's intention will be inferred from his and the trustees' subsequent conduct. ${ }^{173}$ Out of the two trustees, Mr Wilson was the only active trustee.

164 Springett v Dashwood (1860) 2 Giffard 251, 66 ER 218; and Re Skinner [1904] 1 Ch 289.

165 Target Holdings Ltd v Redferns (a firm) [1996] 1 AC 421 (HL) at 434.

166 Re Hay's Settlement Trusts [1982] 1 WLR 202 (Ch).

167 Luke v South Kensington Hotel Co (1879) 11 Ch D121 (CA).

168 John Hart "Trust Administration and Governance - Doing it Right" (paper represented to the New Zealand Law Society Seminar, September 1998) 12 at 12.

169 Wilson, above n 5, at [23].

170 David Hayton "The Hayton Review of Current Trust Law Issues" (paper presented to Transcontinental Trusts Conference, Geneva, June 2009).

171 Wilson, above n 5, at [11], [16] and [96]; and Official Assignee v Wilson [2006] 2 NZLR 841 (HC) at [69], [86] and [103].

172 Official Assignee v Wilson, above n 171, at [65].

173 Apart from Reynolds' and the trustees' subsequent conduct that was discussed by the Court of Appeal in Wilson, the author had the benefit of consulting the acting lawyer (Mr Jim Guest) for the Official Assignee in the Wilson case. Many facts discussed in this article came from Mr Guest's speech at the 2009 New Zealand Law Society Trusts Conference as well as emails exchanges between the author and Mr Guest. 
Mr Wilson did not perform his trustee duties. First, he undertook to look after Reynolds' interests, a non-beneficiary. The trustees agreed to a mortgage sum that was significantly greater than needed. ${ }^{174}$ The excess was paid for Reynolds' personal debt. Under cross-examination, $\mathrm{Mr}$ Wilson admitted that the excessive mortgage was taken out because he was acting for both the trust and Reynolds. ${ }^{175}$ This additional borrowing could have resulted in the trust losing its only equity. ${ }^{176}$ Second, no proper accounts were kept. ${ }^{177}$ For example, in the trust account's ledger the first trust property was recorded in Reynolds' name, ${ }^{178}$ Reynolds' personal affairs including finances were intermingled with those of the trust, ${ }^{179}$ the trust's bank statements were addressed to Reynolds alone, ${ }^{180}$ and there was no documentation on the sale of the first trust property to Reynolds (as well as no payment being made by Reynolds to the trust for this sale). ${ }^{181}$ Like the first trust property, the purchase and financing of the second trust property was also poorly documented. ${ }^{182}$ Third, there were no regular trust meetings. In fact, the only trust meeting (and resolution) convened and recorded was after Reynolds had been declared bankrupt. ${ }^{183}$ Finally, other relevant evidence included the fact that all house outgoings and mortgage repayments were paid by Reynolds, ${ }^{184}$ there was no lease or licence entitling the Reynolds to live in the property, ${ }^{185}$ and the settlor and trustee offered conflicting evidence over several trust transactions. ${ }^{186}$

Several inferences can be drawn from this evidence. First, no documentation other than the trust deed itself indicated that the trust was ever carried into effect. Second, the trustee continued to take account of Reynolds' interest. Third, the intermingling of the settlor's personal affairs with those of the trust and other improper trust account entries are all actions that are inconsistent with a trust relationship which supports the inference that the parties acted without reference to the trust deed.

174 At [88].

175 At [92].

176 At [93].

177 At [103].

178 Guest, above n 12; and this should have been recorded in the trustee's name.

179 Wilson, above n 5, at [11].

180 Guest, above n 12; and this should have been recorded in the trustee's name.

181 Official Assignee v Wilson, above n 171, at [78] and [81].

182 At [86].

183 At [96].

184 Guest, above n 12.

185 Official Assignee v Wilson, above n 171, at [85].

186 At [72]. 
The overall conclusion that can be drawn from the parties' subsequent conduct is that Reynolds did not intend to create a trust. ${ }^{187}$

The trust administration in Wilson was poor, and is reflective of the wider problem in the New Zealand trust industry. ${ }^{188}$ Many settlors and trustees believe that signing a trust deed is enough to evidence an intention to create a trust. There is currently a total lack of education provided by trust practitioners to trustees on the issue of trust management and trustees' duties for the trust to be a valid trust. ${ }^{189}$ This issue should be addressed urgently.

\section{CONCLUSION}

The current academic debate regarding the common intention requirement is born out of confusion over the relevant intention needed for the creation of an express trust. This article emphasises that it is the settlor's intention alone that creates the trust. Where there is a "separate" trustee, the trustee's intention is irrelevant given the trust is complete without any element of acceptance by the trustee.

It is not correct to say that "I have a trust because I have a trust deed". The trust deed will not be conclusive evidence when determining the existence of a trust if the overriding evidence of the settlor's intention as construed by the judge (probably many years later with reference to subjective intention and subsequent conduct) shows that the intention was not to create a trust. Given that the settlor's intention is often inferred from subsequent conduct, if the settlor is to successfully defend a probe into the trust's validity the settlor and the trustee must ensure that their respective conduct is the same as the intent drafted into the trust deed. A trust should be properly administered to avoid the likely conclusion that the settlor did not intend to create the trust because he or she had acted throughout as if he or she was still the owner of the trust property.

The recent focus on "sham trusts" has deflected attention away from the much more fundamental question of certainty of intention (as advocated by the Law Commission). The only question that should concern the court when determining whether or not a trust exists is whether the settlor had a genuine intention to dispose of his or her beneficial interest in the trust property. There is no need to use the word "sham" because when all is said and done, there is either a trust or there is not.

187 This factual conclusion was also reached in Hayton, above n 170.

188 Hart, above n 168, at 15.

189 Maxwell, above n 4, at 9 and 61; and Holmes, above n 159, at [1.4]. 
